\title{
EFFECT OF FLUNIXIN MEGLUMINE AND hCG AT COMMERCIAL PROGRAMS FOR MULTIPLE OVULATION AND EMBRYO TRANSFER (MOET) IN SHEEP
}

\author{
(Efeito do flunixin meglumine e hCG em programas comerciais de múltipla ovulação \\ e transferência de embriões (MOTE) em ovinos)
}

Tácia Gomes Bergstein-Galan ${ }^{1}$, Romildo Romualdo Weiss ${ }^{2}$, Luiz Ernandes Kozicki ${ }^{3}$, Caroline Tomasi Bortoleto $^{2}$, Natália Santana Siqueira Lara ${ }^{2}$, Gláucia Aparecida Aschenbrenner ${ }^{2}$

${ }^{1}$ Departamento de Medicina Veterinária - Universidade Positivo / Alamos Genética, ${ }^{2}$ Departamento de Medicina Veterinária - UFPR, ${ }^{3}$ Departamento de Medicina Veterinária - PUCPR

Corresponding author: tacia@alamos.com.br

\begin{abstract}
Early regression of the corpora lutea (ERCL) reduces the efficiency of multiple ovulation and embryo transfer (MOET) programs in small ruminants. The objective of this study was to evaluate the effect of Flunixin meglumine (FM) and human chorionic gonadotropin (hCG) on embryo recovery in sheep superovulated with FSH and eCG and pregnancy rate in recipients. The study was divided into two parts. In Trial 1, 12 donors were divided into three groups i.e. Control, FM group (1.1mg FM/ kg, SID, from artificial insemination-Al until embryo collection) and hCG group (1000Ul hCG, 84 hours after progesterone device withdrawal). The mean \pm standard error of the quantity of corpus luteum $(\mathrm{CL})$ and the quantity and quality of the recovered embryos were analyzed. In Trial 2, 34 donors were divided into two groups i.e. Control and FM, the mean \pm standard error of the quantity of recovered embryos were evaluated. Fifty-four embryos from each group in trial 2 were transferred into recipients and pregnancy rate was analyzed. In Trial 1, there were more $(P<0.05) C L$ in the FM group than in the control and hCG groups, however there was no difference in embryo quantity or quality. In Trial 2 there was no significant difference in the number of $\mathrm{CL}$ or embryos recovered, nor in the pregnancy rate after embryo transfer. In conclusion, the strategies used in the prevention of ERCL had no effect on embryo recovery or embryo survival.
\end{abstract}

Keywords: Flunixin Meglumine; hCG; FSH; embryo survival.

RESUMO: A regressão prematura do corpo lúteo (RPCL) diminui a eficiência de programas de múltipla ovulação e transferência de embriões (MOTE) em pequenos ruminantes. O objetivo deste estudo foi avaliar o efeito do Flunixin meglumine (FM) e da gonadotrofina coriônica humana (hCG) na recuperação embrionária em ovelhas superovuladas com FSH e eCG e na taxa de gestação das receptoras. $\mathrm{O}$ estudo foi dividido em duas partes. No Experimento 1 doze doadoras foram divididas em três grupos: controle, FM (1.1mg FM/ kg, SID, desde o dia da inseminação artificial até o dia da coleta de embriões) e hCG (1000Ul hCG, 84 horas após a retirada do implante de progesterona). $O$ número médio \pm erro padrão da quantidade de corpos lúteos $(C L)$ e a quantidade e qualidade dos embriões recuperados foram analisados. No Experimento 2, trinta e quatro doadoras foram divididas em dois grupos: controle e FM. O número médio \pm erro padrão de embriões recuperados foram avaliados. Cinquenta e quatro embriões de cada grupo do Experimento 2 foram transferidos em ovelhas receptoras e a taxa de gestação foi analisada. No Experimento 1, foi encontrado maior número $(P<0,05)$ de $C L$ no grupo FM quando comparado aos grupos Controle e hCG, entretanto a quantidade 
e qualidade dos embriões recuperados não diferiu entre os grupos. No Experimento 2 não houve diferença significativa na quantidade de embriões recuperados, tampouco houve diferença na taxa de gestação após transferência dos embriões. Em conclusão, as estratégias usadas na prevenção da RPCL não apresentaram efeito na recuperação ou sobrevivência embrionária.

Palavras-chave: Flunixin Meglumine; hCG; FSH; sobrevivência embrionária. 


\section{INTRODUCTION}

Multiple ovulation and embryo transfer (MOET) is an important tool to increase the progeny of genetically superior females. However, the variability in the ovulatory response and in embryo collection yield per donor are the main limiting factors in large-scale use of this technique in small ruminants (Cognie, 1999). One of the factors contributing to low embryo recovery is early regression of the corpora lutea (ERCL)(Cervantes et al., 2007). ERCL may affect up to $30 \%$ of donors in goat MOET programs (Pintado et al., 1998) and 6.3 to $71.4 \%$ in superovulated sheep (Bosco et al. 2015; Fukui et al., 1998).

The ERCL consists of lysis of the corpora lutea $(\mathrm{CL})$ prior to physiological luteolysis. Consequently, progesterone concentrations decrease to $<1 \mathrm{ng} / \mathrm{ml}$ (Cervantes et al., 2007), usually 3 to 6 days after the onset of estrus (Gilbert et al., 1990; Saharrea et al. 1998). The causes of ERCL are not fully understood, but its occurrence has been associated with high concentrations of estrogen in the initial luteal phase. This situation is common in superovulation programs that used equine chorionic gonadotropin (eCG) - alone or associated with follicle-stimulating hormone $(\mathrm{FSH})$ - probably because of long half-life of eCG and its prolonged effect on the first follicular wave after ovulation (Campanholi e Maciel 2015; Espinosa-Márquez et al., 2004; Saharrea et al., 1998). Another cause of $E R C L$ is the presence of anovulatory follicles or small follicles, recruited by eCG, at the beginning of the luteal phase. These follicles would not be responsive to physiological luteinization because they lack $\mathrm{LH}$ receptors at the time of LH peak (Saharrea et al., 1998).

Battye et al. (1988) proposed that early release of prostaglandins by anovulatory follicles or the uterus would cause ERCL in nanny goats and started investigations using prostaglandin synthesis inhibitors to prevent ERCL. Flunixin Meglumine (FM) is an antiinflammatory non-steroidal antiinflammatory drug that inhibits cyclooxygenase, the enzyme responsible for the conversion of arachidonic acid into prostaglandins. Battye et al. (1988) and Gilbert et al. (1990) reported that two daily applications of FM, for 4 days, beginning 48 hours after the onset of estrus, was effective in decreasing the incidence of ERCL in superovulated goats. Salles et al. (1998) studied the effect of reduced frequency of FM application, using one dose of $1.1 \mathrm{mg} / \mathrm{kg}$ per day, and reported a higher rate of embryo recovery when compared to the use of either $2.2 \mathrm{mg} / \mathrm{Kg}$ SID or $1.1 \mathrm{mg} / \mathrm{kg}-B I D$.

Human chorionic gonadotropin (hCG) has a luteotrophic effect in small ruminants (Kelidari et al., 2010). Researchers aiming to promote luteinization of anovulatory follicles evaluated the effect of administration of hCG in the early luteal phase, on the prevention of ERCL in superovulated goats. (Administration of 250 IU of hCG at onset of estrus was not effective in increasing ovulation rate nor decreasing the number of anovulatory follicles Armstrong et al., 1982). However when $1000 \mathrm{Ul}$ of hCG was injected 84 hours after estrus onset high concentrations of progesterone were maintained until six days after ovulation (Saharrea et al., 1998).

Although many authors have studied the prevention of ERCL using FM and hCG there is little information about pregnancy rate after the implantation of the embryos recovered using these strategies. Moreover, most of the studies of ERCL have been performed in goats although large numbers of sheep donors are also affected by ERCL. 
The objective of this study was to evaluate the effect of two protocols (FM and hCG) for the prevention of premature regression of corpora lutea on embryo recovery in superovulated sheep and pregnancy rate in recipients.

\section{MATERIALS AND METHODS}

\section{Animals}

In Trial 1, twelve donors and six Dorper and White Dorper rams were used. In Trial 2, thirty-four donors, six rams and 108 cross-breed recipients were used. All animals included in the study were aged between 1 and 8 years and presented body condition score ranging from 1 to 5 (Cam et al., 2018). The animals were managed in a semiintensive system, with access to pasture during the day and housed at night. The animals received food supplementation with corn, soybean and mineral mix twice a day and water supply ad libitum.

The study was conducted at Alamos Genetics Flushing Station, latitude $25.46^{\circ} \mathrm{S}$ and longitude $49.69^{\circ} \mathrm{W}$ during the non-breeding season (September to January).

\section{Ethical statement}

The authors declare that this study was carried out in accordance with the U.K. Animals (Scientific Procedures) Act, 1986 and associated guidelines, EU Directive 2010/63 / EU for animal experiments.

\section{Experimental design}

Trial 1

Twelve ewes were divided into three groups: control group $(n=4)$ were synchronized using intravaginal devices impregnated with $0.33 \mathrm{~g}$ of progesterone (Eazi-Breed CIDR ${ }^{\circledR}$, Zoetis, USA) for 14 days. Devices were replaced on day seven of treatment. Superovulation was induced by the administration of $240 \mathrm{mg}$ $\mathrm{NIH}-\mathrm{FSH}-\mathrm{S} 1$ FSH-P1 (Folltropin $^{\circledR}$, Telesta Therapeutics Inc., Canada) divided into eight applications of decreasing doses from the twelfth day of treatment. At the time of the last FSH injection the progesterone device was withdrawn and 200 IU eCG (Novormon ${ }^{\circledR}$, Zoetis, United States) was administered. In group FM $(n=4), 5$ doses of $1.1 \mathrm{mg} / \mathrm{kg}-\mathrm{IM}$ of Flunixin Meglumine (Banamine $^{\circledR}$, Schering-Plough, USA) were administered at 24-hour intervals from the day of artificial insemination (Al)(Salles et al.,1998). In the hCG group, the donors $(n=4)$ were treated with 1000 IU-IM of hCG (Vetecor, Ceva Saúde Animal Ltda, Brazil) 84 h after intravaginal devices withdrawal Saharrea et al. (1998).

The number and morphology of donors' corpora lutea (CL) were evaluated five days after Al. CL were morphologically classified as normal (bright red) or regressed (light pink or white)(Figure 1)(Cervantes et al., 2007; Espinosa-Márquez et al. 2004; Farin et al. 1996). Donors with three or more CL were forwarded for embryo collection. After embryo collection, the number and grade of the embryos were evaluated according to the International Embryo Transfer Society (IETS) standard (2002). Three sheep were excluded from the study (one from each group) because they did not have the minimum number of CL.

\section{Trial 2}

During the non-breeding season, 34 ewes were divided into two groups i.e. control group $(n=17)$ and FM group ( $n$ $=17$ ). The same methods as in Trial 1 were used. After the collection procedures 54 grade 1 embryos per group, were selected for implantation in recipients.

Artificial insemination, embryo collection and recipient synchronization

Fresh semen was obtained from rams housed at Álamos Genetics Flushing Station using an artificial 
vagina. Semen analysis was performed under optical microscopy (Coleman, N 107, Brazil). Spermatic samples with total motility $\geq 30 \%$ and turbulence score $\geq 3$ were used for Al. The inseminating dose was standardized to $400 \times 10^{6}$ spermatozoa/ donor.

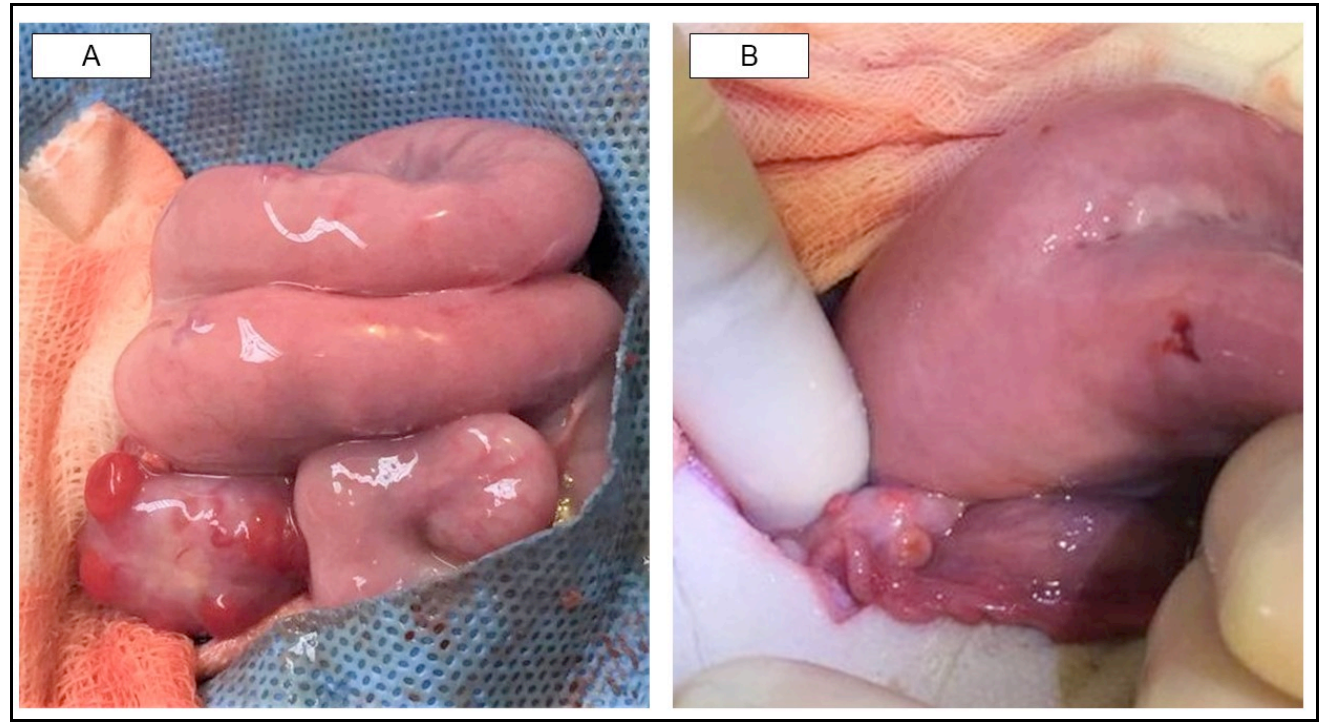

Figure 1. Morphological classification of corpora lutea in sheep donors. A- Normal: bright red color and physiological size. B- Regressed: light pink or white color and smaller size.

Artificial insemination (Al) of the donor was carried out 40 hours after progesterone device withdrawal and repeated six hours later. A laparoscopic technique was used. Donors were fasted for at least 12 hours and sedated with acepromazine $(0.05 \mathrm{mg} / \mathrm{kg})$ before being placed in the Trendelenburg position. The uterine horns were visualized with a $5 \mathrm{~mm}$ and $30^{\circ}$ angulated laparoscope (Karl Stroz, Tuttlingen, German). The spermatozoa were deposited into the uterine lumen in the middle of the uterine horn using an Robertson pipet (Minitube Brasil, Porto Alegre, Brazil) (Bergstein-Galan et al. 2017a; Bergstein-Galan et al., 2017b).

Embryo collections were performed by laparotomy five days after Al. Donors were fasted for at least 24 hours and sedated with Acepromazine $1 \%(0.05 \mathrm{mg} / \mathrm{kg}, \mathrm{IM})$ and anesthetized with Isoflurane. An approximately $7 \mathrm{~cm}$ long incision was made through skin, subcutaneous tissue, abdominal musculature and peritoneum in the linea alba. The uterine horns were externalized. A Foley catheter was positioned in the initial distal third of each uterine horn. After inflation of the probe balloon the surgeon inserted a $20 \mathrm{G}$ catheter into the proximal third of the uterine horn. Twenty-five milliliters of PBS were infused from the catheter into each uterine horn and collected through the Foley probe into a petri dish. Finally, uterine horns were repositioned and the musculature, subcutaneous tissue and skin were sutured (Bergstein-Galan et al., 2018a; Bergstein-Galan et al., 2018b).

Collected embryos were transferred immediately to the recipient sheep using a semi laparoscopic technique (Bari et al., 2003). One embryo was transferred to each recipient after the verification of at least one $\mathrm{CL}$ in the recipient's ovary.

The recipients' estrous cycles were synchronized with intravaginal devices impregnated with $60 \mathrm{mg}$ of medroxyprogesterone acetate 
(Progespon $^{\circledR}$, Zoetis, United States) for a period of 14 days. On the day of device removal 500 IU of eCG (Novormon ${ }^{\circledR}$, Zoetis, United States) was administered and recipients remained with vasectomies rams for a period of 48 hours. Embryos were transferred to recipients five days after device withdraw.

Transabdominal ultrasonographic pregnancy diagnosis was performed at 60 days after implantation of embryos using a $5 \mathrm{mHz}$ linear probe (DP2200 Vet, Mindray Medical International Limited, Shenzhen, China).

\section{Statistics}

Software Stat Action ${ }^{\circledR}$ version 3.1.43.724.694 was used for all statistical analyzes. Data from Trial 1 showed normal distribution in AndersonDarling test and equal variances in Leveane test. The difference between the groups (Control, FM and hCG) was evaluated by Anova One-way test followed by Fisher's test. In Trial 2 the variable number of embryos had normal distribution and different variances, Mann-Witney test was used to compare the groups (Control and FM). The variable Pregnancy rate in Trial 2 showed normal distribution and equal variances in the $F$ test, in this variable the $T$ test was applied with independent samples and equal variances. In all tests the level of significance was $5 \%$

\section{RESULTS}

\section{Trial 1}

In the laparoscopic evaluation, one donor $(1 / 3-33.33 \%)$ with coloration of $C L$ indicative of ERCL was identified in the hCG group. However, as the number of $\mathrm{CL}$ was higher than the criterion for embryo collection, collection was made from this donor, but no embryos were recovered. One donor from the control group and one from the hCG group had fewer $\mathrm{CL}$ than the cut off limit and therefore no collection was made. A donor from the FM group had no $C L$ on ovarian evaluation and was withdrawn from the study. No donors from the control or FM groups had CL with morphology suggestive of ERCL.

Table 1 shows the mean \pm standard error of the number of $\mathrm{CL}$, total embryos recovered and classified (grade 1 and grade 2) in the experimental groups. The FM group had more $(P<0.05) \quad C L$ when compared to the other groups. The number of embryos recovered, and embryos classified as Grade 1 and 2 did not differ between the groups.

Table 1. Mean \pm standard error of the number of corpora lutea $(C L)$, total embryos recovered and classified (grade 1 and grade 2) per donor superovulated with Control protocol, plus 5 applications of flunixin meglumine (FM) or plus an application of human chorionic gonadotropin (hCG).

\begin{tabular}{cccccc}
\hline Group & $\boldsymbol{n}$ Donors & CL & Embryos & Grade 1 & Grade 2 \\
\hline Control & 3 & $4.0 \pm 0.0^{\mathrm{b}}$ & $7.66 \pm 2.72$ & $4.66 \pm 0.66$ & $2.0 \pm 2.0$ \\
FM & 3 & $9.33 \pm 1.76^{\mathrm{a}}$ & $8.0 \pm 0.88$ & $6.33 \pm 0.88$ & $1.66 \pm 0.88$ \\
hCG & 3 & $4.66 \pm 0.88^{\mathrm{b}}$ & $3.33 \pm 2.02$ & $3.33 \pm 2.02$ & $0.0 \pm 0.0$ \\
\hline \multicolumn{7}{l}{ Different letters in the same column indicate significant difference $(\mathrm{P}<0.05)$ between results. }
\end{tabular}

Trial 2

One donor in the control group (1/17-5.88\%) had CL with morphology consistent with ERCL on laparoscopic evaluation before embryo collection, in this collection the donor produced 14 embryos. No donor in FM group (0/17$0 \%$ ) showed signs of ERCL in Trial 2.

Donors from the Control group produced 151 embryos and 131 
embryos were recovered from $F M$ group. The mean \pm standard error of the number of embryos recovered per donor is shown in Table 2. There was no difference $(P>0.05)$ in the number of embryos recovered, or pregnancy rate after transfer, of the embryos between the control group and FM (Table 2).

Table 2. Mean \pm standard error of the number of embryos recovered per donor and percentage of pregnancies after transfer of embryos recovered from ewes superovulated with Control protocol or control protocol plus 5 applications of flunixin meglumine (FM).

\begin{tabular}{ccccc}
\hline \multirow{2}{*}{ Group } & $\boldsymbol{n}$ Donors & Embryos & $\boldsymbol{n}$ IE & Percentage \\
\hline Control & 17 & $8.88 \pm 1,84$ & 54 & $25.31 \pm 5.10$ \\
FM & 17 & $7.70 \pm 0.95$ & 54 & $25.56 \pm 8.73$ \\
\hline
\end{tabular}

$n$ IE: number of embryo transfered

Figure 2 shows a Boxplot of pregnancy rate per treatment per donor. The first quartile is $1.92 \%$ in the control group and $16.66 \%$ in FM. The pseudo median is $19.64 \%$ and $25 \%$ in the control and FM groups respectively.
Third quartile is $47.72 \%$ in the control group and $40.0 \%$ in the FM group. The minimum was $0 \%$ in both groups and the maximum was $66.66 \%$ and $50.0 \%$ in the control and FM groups, respectively.

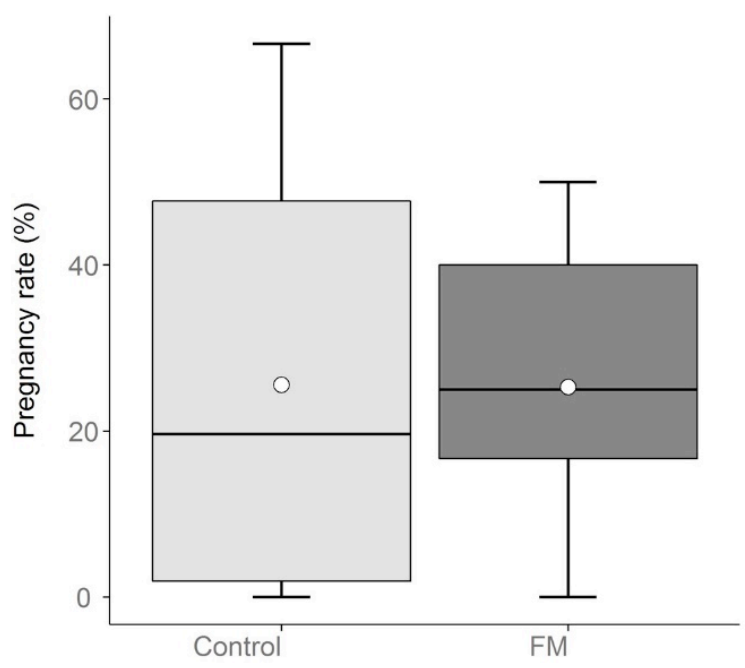

Figure 2. Bloxplot of pregnancy rate (\%) in recipient ewes when embryos were collected from donors undergoing Control protocol or receiving five doses of Fluninin Meglumine (FM) between day of ovulation and embryo collection.

\section{DISCUSSION}

ERCL is one of the main factors related to low embryo recovery in MOET in small ruminants. Several strategies have been attempted to reduce ERCL in ovine and caprine superovulation programs, among these the use of FM between $\mathrm{Al}$ and embryo collection or
hCG in the initial luteal phase have shown good results (Battye et al., 1988; Saharrea et al., 1998; Salles et al., 1998). The purpose of this study was to evaluate the embryonic recovery and pregnancy rate after embryo transfer when these ERCL prevention strategies are used. 
The number of donors showing signs of ERCL on laparoscopic evaluation in the control group $(0 \%$ - Trial 1 and $5.88 \%$ - Trial 2) was lower than that reported in other studies (Bosco et al., 2015; Fukui et al.; 1998). It is possible that this finding is a result of the time of year in which the collections were performed (Spring and Summer), since ERCL is more frequent in the autumn (Fukui et al., 1998; Ryan et al., 1991). The finding of a donor in the hCG group (Trial 1) with CL morphology suggestive of ERCL was not expected, it is possible there had been inappropriate synchronization between the stage of follicular development and the time of exposure to exogenous $\mathrm{LH}$ (hCG) in this animal.

In Trial 1 the number of CL observed in the FM group was higher $(P<0.05)$ than that in the Control and hCG groups, however, the number and quality of the embryos recovered did not differ between groups (Table 1). According to Gilbert et al. (1990), although the administration of FM between ovulation and embryo collection decreases the incidence of donors with ERCL, this does not seem to affect embryo recovery and embryo quality. In the hCG group, one of the donors showed signs suggestive of ERCL, in addition a smaller $(P>0.05)$ number of $C L$ and embryos were recovered. Although this result was unexpected, Kelidari et al. (2010) had shown that protocols with two doses of 500Ul of hCG on day 0 and 1 or 2 after sponge removal are more effective in maintaining high concentrations of progesterone at day 8 and preventing ERCL in superovulated goats.

In Trial 2, more embryos were recovered in both the Control group and FM group than previously reported from Dorper sheep (Bosco et al., 2015; Gusmão et al., 2009; Ocak et al., 2013). There was no significant difference in the number of embryos recovered nor pregnancy rate between groups. These results corroborate the results from Trial 1 , where there was no difference in embryo quality between groups, which is a significant factor in embryo survival rate after implantation (Bari et al., 2003; Zohara et al., 2017). Of note is that the embryos were recovered on day 5 after ovulation and ERCL occurs between 3 and 6 days after ovulation (Gilbert et al.,1990; Saharrea et al., 1998). It is possible that the absence of a difference is the result of early recovery of the embryos, by which time there had been no significant decrease in progesterone through the ERCL.

Although there was no difference in the mean and standard error of the gestation rate between the Control and FM groups (Table 2), Figure 2 clearly demonstrates a greater variability of the gestation rate in the Control group. The reason for this variability is not known however, embryonic survival after implantation is dependent on numerous factors including factors related to ERCL i.e. abnormal embryo development (Armstrong et al., 1982), embryo grade (Zohara et al., 2017), development stage (Alabart et al., 2003) and factors not related to ERCL i.e. degree of synchronization between donor and recipient (Alabart et al., 1995), recipients' age (Bari et al., 2003) and recipients' plasma progesterone concentration (Alabart et al., 2003).

\section{CONCLUSIONS}

The evaluation of $\mathrm{FM}$ and $\mathrm{hCG}$ effect on the prevention of ERCL was compromised by the low number of donors who showed morphological signs of ERCL in the control group. The Flunixin Meglumine protocol produced more corpora lutea., The embryo recovery and pregnancy rates after embryo transfer were not different from 
the control group. More studies are needed to better understand the difference in gestation rate variability after embryo implantation.

\section{REFERENCES}

ALABART, J. L.; FOLCH, J.; FERNÁNDEZ-ARIAS, A.; et al. Screening of some variables influencing the results of embryo transfer in the ewe part II: Two-day-old embryos. Theriogenology, v. 59, n. 5-6, p. 13451356, 2003.

ALABART, J. L.; FOLCH, J.; FERNÁNDEZ-ARIAS, A.; et al. Screening of some variables infliencing the results of embryo transfer in the ewe. I. Five-day-old embryos. Theriogenology, v. 44, p. 1011-1026, 1995.

ARMSTRONG, D. T.; PFITZNER, A. P.; PORTER, K. J.; et al. Ovarian responses of anoestrous goats to stimulation with pregnant mare serum gonadotrophin. Animal Reproduction Science, v. 5, n. 1, p. 15-23, 1982. Elsevier. Disponível em: <https://www.sciencedirect.com/science/ article/pii/0378432082900331>. Acesso em: 9/4/2018.

BARI, F.; KHALID, M.; HARESIGN, W.; MURRAY, A.; MERRELL, B. Factors affecting the survival of sheep embryos after transfer within a MOET program. Theriogenology, v. 59, n. 5-6, p. 12651275, 2003.

BATTYE, K. M.; FAIRCLOUGH, R. J.; CAMERON, A. W. N.; TROUNSON, A. O. Evidence for prostaglandin involvement in early luteal regression of the superovulated nanny goat (Capra hircus). Journal of Reproduction and Fertility, v. 84, n. 2, p. 425-430, 1988.

BERGSTEIN-GALAN, T. G.; BUSATO, E. M.; ABREU, A. C. M.; WEISS, R. R. Artificial Insemination and Embryo
Transfer in Small Ruminants. In: T. G. Bergstein-Galan (Org.); Reproduction Biotechnology in Farm Animals. $1^{\circ}$ ed, p.181-199, 2018. Avid Science.

BERGSTEIN-GALAN, T. G.; WEISS, R. R.; BERTOL, M. A. F.; et al. Quality and fertility of frozen ovine spermatozoa from epididymides stored at room temperature (18e25 ?C) for up to $48 \mathrm{~h}$ post mortem. Theriogenology, v. 96, p. 69-75, 2017. Disponível em: <http://www.sciencedirect.com/science/a rticle/pii/S0093691X17301516>. Acesso em: 25/5/2017.

BERGSTEIN-GALAN, T. G.; WEISS, R. R.; KOZICKI, L. E. Effect of semen and donor factors on multiple ovulation and embryo transfer (MOET) in sheep. Reproduction in Domestic Animals, v. 54, n. 2, p. 401-407, 2018.

BERGSTEIN-GALAN, T. G.; WEISS, R. R.; KOZICKI, L. E.; BICUDO, S. D. Sperm subpopulations in ejaculated sperm and spermatozoa recovered from ovine epididymides up to $48 \mathrm{~h}$ after death. Animal Reproduction Science, v. 187, p. 20-27, 2017. Elsevier. Disponível em: <https://www.sciencedirect.com/science/ article/pii/S0378432017302786>.

Acesso em: 9/4/2018.

BOSCO, J.; FILHO, L.; PAINS, A.; et al. Effect of $\mathrm{pFSH}$ dose reduction on in vivo embryo production in Dorper ewes. Semina: Ciências Agrárias, v. 36, n. 6 , p. 4215-4224, 2015.

CAM, M. A.; GARIPOGLU, A. V.; KIRIKCI, K. Body condition status at mating affects gestation length, offspring yield and return rate in ewes. Archives Animal Breeding, v. 61, n. 2, p. 221228, 2018.

CAMPANHOLI, S. P.; MACIEL, G. S. Regressão luteal prematura em pequenos ruminantes. Rev. Bras. Reprod. Anim., v. 39, n. 2, p. 270-276, 2015. 
CERVANTES, M. J.; JUÁREZ, M. L.; MEJÍA, V. O.; et al. Use of fluorogestone acetate after breeding to reduce the effect of premature luteal regression in dairy goats when superovulation is induced with FSH. Animal Reproduction Science, v. 97, n. 1-2, p. 47-54, 2007. Elsevier. Disponível em: $<$ https://www.sciencedirect.com/science/ article/pii/S0378432006000285>.

Acesso em: 27/3/2018.

COGNIE, Y. State of the art in sheepgoat embryo transfer. Theriogenology, v. 51, n. 1, p. 105-116, 1999.

ESPINOSA-MÁRQUEZ,

M.

VALENCIA, J.; ZARCO, L.; et al. Effect of fluorogestone acetate on embryo recovery and quality in eCGsuperovulated goats with premature luteal regression. Theriogenology, $v$. 62, n. 3-4, p. 624-630, 2004. Elsevier. Disponível

em:

<https://www.sciencedirect.com/science/ article/pii/S0093691X04000123>.

Acesso em: 27/3/2018.

FARIN, C. E.; MOELLER, C. L.; SAWYER, H. R.; GAMBONI, F.; NISWENDER, G. D. Morphometric analysis of cell types in the ovine corpus luteum throughout the estrous cycle. Biology of reproduction, v. 35, n. 5, p. 1299-1308, 1996.

FUKUI, Y.; OKADA, M.; ISHIDA, N. Incidence of premature luteal regression in ewes superovulated with a single injection of follicle-stimulating hormone combined with equine chorionic gonadotropin. Journal of reproduction and development, v. 44 , n. 4 , p. 407412, 1998.

GILBERT, D. E.; COONROD, S. A.; WHITING, C. J.; PASHEN, R. L. Comparison of a progesterone intravaginal device $\left(\mathrm{CIDR}^{\mathrm{TM}}\right)$ with flunixine meglumine (Finadyne ${ }^{\mathrm{TM}}$ ) for reducing the effects of corpora lutea regression in the goat. Theriogenology, v. 33, n. 1, p. 230, 1990. Elsevier. Disponível em: <https://www.sciencedirect.com/science/ article/pii/0093691X9090654C>. Acesso em: 30/3/2018.

GUSMÃO, A. L.; SILVA, J. C.; BITTENCOURT, T. C. C.; et al. Coleta transcervical de embriões em ovinos da raça Dorper no semiárido do Nordeste Brasileiro. Arquivo Brasileiro de Medicina Veterinaria e Zootecnia, v. 61, n. 2, p. 313-318, 2009.

KELIDARI, H. R.; SOURI, M.; SHABANKAREH, H. K.; HASHEMI, S. B. Repeated administration of hCG on follicular and luteal characteristics and serum progesterone concentrations in eCG-superovulated does. Small Ruminant Research, v. 90, n. 1-3, p. 95-100, 2010. Elsevier. Disponível em: $<$ https://www.sciencedirect.com/science/ article/pii/S0921448810000416>.

Acesso em: 27/3/2018.

OCAK, S.; EMSEN, E.; OGUN, S. Ovulation rate and embryo yield of dorper sheep in non-breeding season under different superovulatory protocols. Journal of animal and veterinary advances, v. 12 , n. 6 , p. 726-730, 2013.

PINTADO, B.; GUTIÉRREZ-ADÁN, A.; LLANO, B. P. Superovulatory response of murciana goats to treatments based on PMSG/anti-PMSG or combined FSH/PMSG administration. Theriogenology, v. 50, n. 3, p. 357364, 1998. Elsevier. Disponível em: <https://www.sciencedirect.com/science/ article/pii/S0093691X98001459>.

Acesso em: 10/4/2018.

RYAN, J. P.; HUNTON, J. R.; MAXWELL, W. M. Increased production of sheep embryos following superovulation of Merino ewes with a combination of pregnant mare serum gonadotrophin and follicle stimulating hormone. Reproduction , Fertility and 
Development, v. 3, n. 5, p. 551-560, 1991.

SAHARREA, A.; VALENCIA, J.; BALCÁZAR, A.; et al. Premature luteal regression in goats superovulated with pmsg: Effect of hCG OR GnRH administration during the early luteal phase. Theriogenology, v. 50, n. 7, p. 1039-1052, 1998. Elsevier. Disponível em:

<https://www.sciencedirect.com/science/ article/pii/S0093691X98002064>.

Acesso em: 26/3/2018.

SALLES, H. O.; SOARES, A. T.; ANDRIOLI, A.; M., S. P. A.; AZEVEDO, H. C. Diferentes Posologias De Flunixin Meglumine $\mathrm{Na}$ Prevenção. Ciência Animal, v. 8, n. 2, p. 69-74, 1998.

ZOHARA, B. F.; AZIZUNNESA; ISLAM, M. F.; ALAM, M. G. S.; BARI, F. Y. Survival of embryos after transfer within multiple ovulation and embryo transfer (MOET) programme. Small Ruminant Research, v. 149, p. 11-15, 2017. Elsevier. Disponível em: $<$ http://linkinghub.elsevier.com/retrieve/p $\mathrm{ii} / S 092144881630311 \mathrm{X}>$. Acesso em: $16 / 4 / 2017$. 